\title{
The role of aldose reductase gene in the susceptibility to diabetic nephropathy in Type II (non-insulin-dependent) diabetes mellitus
}

\author{
D.K. Moczulski ${ }^{1,2}$, W. Burak ${ }^{1,2}$, A. Doria ${ }^{1}$, M. Zychma ${ }^{1,2}$, E. Zukowska-Szczechowska ${ }^{2}$, J.H. Warram ${ }^{1}$, \\ W. Grzeszczak ${ }^{2}$ \\ ${ }^{1}$ Research Division, Joslin Diabetes Center, Boston, USA \\ ${ }^{2}$ Department of Internal Medicine and Diabetology, Silesian School of Medicine, Zabrze, Poland
}

\begin{abstract}
Summary The dinucleotide repeat polymorphism $\left(5^{\prime}\right.$-ALR2) in the promoter region of the aldose reductase gene on chromosome $7 \mathrm{q} 35$ has been implicated in the development of diabetic nephropathy in Type I (insulin-dependent) diabetes mellitus, and markers flanking the aldose reductase locus have given evidence suggestive of a linkage between diabetic nephropathy and Type II (non-insulin-dependent) diabetes mellitus in Pima Indians. To examine whether the $5^{\prime}$-ALR2 polymorphism in the aldose reductase gene is involved in the development of diabetic nephropathy in Caucasians with Type II diabetes, we carried out a large association study. Patients with Type II diabetes from one outpatient clinic were screened for diabetic nephropathy and divided into three groups according to the degree of this disease: 179 patients with normoalbuminuria, 225 patients with microalbuminuria and 70 patients with proteinuria. $\mathrm{Pa}-$ tients with normoalbuminuria were included in the
\end{abstract}

study only if they had had Type II diabetes for 10 or more years. DNA from all patients was genotyped for the 5'-ALR2 polymorphism using a previously established polymerase chain reaction protocol. The frequency of the putative risk allele Z-2 was $34.6 \%$, $34.2 \%$ and $33.6 \%$ in the normoalbuminuria, microalbuminuria and proteinuria groups, respectively. Similarly no difference among groups was found for the frequency of the putative protective allele $Z+2$. In conclusion, the results of our association study in Caucasian patients with Type II diabetes do not support the hypothesis that the 5 '-ALR2 polymorphism in the aldose reductase gene contributes to susceptibility to diabetic nephropathy. Diabetologia (1999) 42: 94-97

Keywords Diabetic nephropathy, genetic susceptibility, aldose reductase, Type II diabetes mellitus.
An excessive flux through the polyol (sorbitol) pathway has long been thought to be involved in the pathogenesis of diabetic microvascular complications [1]. Aldose reductase is the first and rate-limiting enzyme of the polyol pathway which catalyses the NADPH-dependent reduction of glucose to sorbitol.

Received: 4 May 1998 and in revised form: 20 July 1998

Corresponding author: W. Grzeszczak, MD, Ph.D., Department of Internal Medicine and Diabetology, Ul. 3 Maja 13/15, 41-800 Zabrze, Poland

Abbreviations: AR, Aldose reductase; 5'-ALDR2, dinucleotide repeat polymorphism in promoter of aldose reductase gene; ACR, albumin to creatinine ratio; PCR, polymerase chain reaction.
It is possible that variation within the genes coding for the enzymes of the polyol pathway explain why only some patients with diabetes are affected by diabetic nephropathy.

The aldose reductase gene (AR), which is localized to chromosome 7q35, consists of 10 exons and extends over $18 \mathrm{~kb}$ [2]. A polymorphic dinucleotide repeat polymorphism (5'-ALR2) was localized 2.1 $\mathrm{kb}$ upstream of the transcription start site of this gene [3]. A recent study showed strong association between the 5 '-ALR2 and diabetic nephropathy in Caucasian patients with Type I (insulin-dependent) diabetes mellitus [4]. In Type II (non-insulin-dependent) diabetes mellitus, a genome screen of affected sib-pairs with diabetic nephropathy among diabetic Pima Indians found a linkage between diabetic neph- 
Table 1. Clinical characteristics of patients used in the study according to nephropathy status (means \pm SD)

\begin{tabular}{lccr}
\hline & $\begin{array}{l}\text { Control patients } \\
\text { with normoalbuminuria }\end{array}$ & $\begin{array}{l}\text { Patients with } \\
\text { microalbuminuria }\end{array}$ & $\begin{array}{l}\text { Patients with } \\
\text { proteinuria }\end{array}$ \\
\hline Number & 179 & 225 & 70 \\
Age at examination (years) & $62.8 \pm 8.6$ & $62.1 \pm 9.1$ & $62.6 \pm 7.8$ \\
Age at Type II diagnosis (years) & $45.9 \pm 8.6$ & $47.8 \pm 8.7$ & $47.1 \pm 9.5$ \\
Duration of Type II after diagnosis (years) & $16.8 \pm 5.4$ & $14.2 \pm 6.5$ & $15.5 \pm 6.8$ \\
BMI in kg/m ${ }^{2}$ & $29.1 \pm 4.0$ & $29.4 \pm 4.6$ & $28.7 \pm 3.6$ \\
HbA $_{1 \mathrm{c}}$ in $^{\text {a }}$ & $8.0 \pm 1.6$ & $8.1 \pm 1.8$ & $8.3 \pm 1.8$ \\
\hline
\end{tabular}

${ }^{a}$ Normal value: $4.1-6.1 \%$

ropathy and markers close to the AR locus [5]. This suggests that the AR gene could be involved in susceptibility to diabetic nephropathy.

In this report we examine the association between the $5^{\prime}$-ALR2 polymorphism in the aldose reductase gene and diabetic nephropathy in a large group of Caucasian patients with Type II diabetes.

\section{Subjects and methods}

Study group. The first ten patients seen each day during the period June-November 1996 at the Diabetes Outpatient Clinic, Department of Internal Medicine and Diabetes in Zabrze, Poland, were enrolled into the study. All enrolled patients with Type II diabetes underwent a physical examination. They provided information about their age at diagnosis of diabetes, past and current treatment and presence of late diabetic complications. Each patient also provided a random urine sample for urinalysis and determination of the albumin/creatinine ratio (ACR), and blood samples for biochemical analysis and DNA isolation. The protocol for the study was approved by the Local Human Subjects Committee at the Silesian School of Medicine; the subjects informed consent was obtained.

Diagnosis of diabetic nephropathy. Medical history and measurements of ACR in the urine sample collected at the time of the first examination were used to determine the status of diabetic nephropathy. The ACR was determined by measuring the concentration of albumin in the urine with an immunoturbidometric assay on TurbiTimer with Albumin-Urine kits (Behring Diagnostics, Frankfurt/Main, Germany) and that of creatinine with a spectrophotometry method (Kodak, Rochester, N. Y., USA). Patients without any history of diabetic nephropathy and ACR value less than $1.9 \mathrm{mg} / \mathrm{mmol}$ for men and less than $2.8 \mathrm{mg} / \mathrm{mmol}$ for women were considered normoalbuminuric (DN-) [6]. Microalbuminuria was diagnosed when a patient had an ACR of $1.9 \mathrm{mg} / \mathrm{mmol}$ or more but less than $28.2 \mathrm{mg} / \mathrm{mmol}$ for men and $2.8 \mathrm{mg} / \mathrm{mmol}$ or more but less than $40.2 \mathrm{mg} / \mathrm{mmol}$ for women [6]. Proteinuria was diagnosed if ACR values were above $28.2 \mathrm{mg} / \mathrm{mmol}$ for men and $40.2 \mathrm{mg} / \mathrm{mmol}$ for women. Altogether 941 patients with Type II diabetes were identified. Patients with normoalbuminuria who had had diabetes for less than 10 years were excluded. The rest were asked to provide random urine samples for determination of the ACR at the two subsequent clinic visits. Classification of a patient's renal status was based on a consensus of two out of three determinations. DNA from 474 patients who provided three urine samples for ACR determination were used for genotyping. Three study groups were formed: 179 patients classified as normoalbuminuric, 225 patients clas- sified as microalbuminuric and 70 patients with overt proteinuria or chronic renal failure.

All patients included in the study were Caucasians. They were classified as having Type II diabetes according to National Diabetes Data Group criteria. Patients with Type I diabetes were excluded from the study.

Genetic markers and genotyping. To test the previously reported association [4], we genotyped the $5^{\prime}$-ALR 2 polymorphism in the promoter of the aldose reductase gene $[3,4]$ in all 474 patients. Genotyping for the 5'-ALR2 marker was done by polymerase chain reaction (PCR)-based protocols using the previously reported primer sequences [3]. The forward PCR primer was end labelled with $(32 \gamma)$-P-ATP by T4 polynucleotide kinase (Promega, Madison, Wis., USA) according to the manufacturer's protocol. The denatured PCR product was resolved electrophoretically on the polyacrylamide gels and dried gels were exposed to $\mathrm{x}$-ray films.

Statistical analysis. All statistical analyses were made with SAS for Windows v6.12 (SAS Institute, Cary, N. C., USA). Quantitative variables were tested by analysis of variance and frequencies were tested by chi-squared tests.

\section{Results}

The three study groups (control patients with normoalbuminuria, patients with microalbuminuria and those with proteinuria) did not differ with regard to age at examination, age at diagnosis of Type II diabetes, its duration, BMI or $\mathrm{HbA}_{1 \mathrm{c}}$ (Table 1 ).

The distribution of alleles of the $5^{\prime}$-ALR2 polymorphism was similar in all three study groups $\left(\chi^{2}=0.32, p=0.988,4\right.$ df) (Table 2). Specifically, the Z-2 allele, associated with diabetic nephropathy [4], was not more frequent in cases with microalbuminuria or proteinuria than in patients with normoalbuminuria. Also the $\mathrm{Z}+2$ allele, reported as protective against diabetic nephropathy [4], was equally frequent in all the study groups. Similarly, the frequencies of $\mathrm{Z} / \mathrm{Z}-2, \mathrm{Z}-2 / \mathrm{Z}-2$ as well as $\mathrm{Z} / \mathrm{Z}+2$ and $\mathrm{Z}+2 /$ $Z+2$ genotypes were not different among the study groups (data not shown). 
Table 2. Distribution of 5'-ALR2 alleles in the study groups

\begin{tabular}{|c|c|c|c|c|c|c|c|}
\hline \multirow[t]{2}{*}{ ALLELE } & \multirow[t]{2}{*}{ Size } & \multicolumn{2}{|c|}{$\begin{array}{l}\text { Control patients } \\
\text { normoalbuminuria }\end{array}$} & \multicolumn{2}{|c|}{$\begin{array}{l}\text { Patients with } \\
\text { microalbuminuria }\end{array}$} & \multicolumn{2}{|c|}{$\begin{array}{l}\text { Patients with } \\
\text { proteinuria }\end{array}$} \\
\hline & & $\%$ & $(n)$ & $\%$ & $(n)$ & $\%$ & $(n)$ \\
\hline $\mathrm{Z}+6$ & 144 bp & 1.7 & (6) & 0.9 & (4) & 0.7 & (1) \\
\hline $\mathrm{Z}+4$ & 142 bp & 5.0 & (18) & 3.6 & (16) & 4.3 & (6) \\
\hline $\mathrm{Z}+2$ & 140 bp "Protective" & 8.4 & (30) & 7.6 & (34) & 8.6 & (12) \\
\hline $\mathrm{Z}$ & $138 \mathrm{bp}$ & 47.2 & (169) & 50.9 & (229) & 50.0 & (70) \\
\hline $\mathrm{Z}-2$ & 136 bp "Risk"a & 34.6 & (124) & 34.2 & (154) & 33.6 & (47) \\
\hline $\mathrm{Z}-4$ & 134 bp & 2.5 & (9) & 2.0 & (9) & 2.9 & (4) \\
\hline Others & & 0.6 & (2) & 0.8 & (4) & 0.0 & $(0)$ \\
\hline $\begin{array}{l}\text { Total number } \\
\text { of chromosomes }\end{array}$ & & 100.0 & (358) & 100.0 & $(450)$ & 100.0 & (140) \\
\hline
\end{tabular}

${ }^{\mathrm{a}} \chi^{2}=0.32, p=0.988(4 \mathrm{df})$ comparing frequencies of $\mathrm{Z}+2, \mathrm{Z}-2$ and all other alleles combined in the three study groups

\section{Discussion}

The AR gene has been proposed as a candidate gene for the development of late diabetic complications [7]. A recent study of 75 Type I diabetic patients with diabetic nephropathy and 38 without, found that patients with the Z-2 allele were at high risk for diabetic nephropathy whereas those with the $Z+2$ allele were protected from this complication [4]. In Type II diabetes there is an indirect evidence for an involvement of the AR gene in the development of diabetic nephropathy from a study of Pima Indians [5]. Using sib pairs concordant for diabetic nephropathy, a linkage between the chromosome $7 \mathrm{q}$ region containing the AR gene and diabetic nephropathy was found [5].

Results of our study do not agree with the above observations and do not support the hypothesis that the $5{ }^{\prime}$-ALR2 dinucleotide repeat polymorphism in the promoter of aldose reductase gene is associated with a susceptibility to diabetic nephropathy in patients with Type II diabetes.

The disagreement between our data and those in Pima Indians [5] could result from different study designs. The affected sib-pair analysis in Pima Indians showed positive linkage between diabetic nephropathy and the chromosomal region where the AR gene is located, suggesting that the region contains a DNA polymorphism contributing to susceptibility to diabetic nephropathy. This polymorphism, however, could be located outside of the AR locus. It is also possible that the genetic variability in the AR gene contributes to diabetic nephropathy in Pima Indians but not in Caucasian patients with Type II diabetes [8].

There are two possibilities for the differences between our negative results and the previous positive findings [4]. Firstly that the association between certain $5^{\prime}$-ALR2 alleles and diabetic nephropathy is true in Type I but not in Type II diabetes. This could occur if the aetiology of the complication is different in each type of diabetes. Support for this comes from a recent kidney biopsy study which showed that Type II diabetic patients with microalbuminuria have heterogeneous renal lesions with less than one third of the patients having "typical" diabetic nephropathy [9]. Morphological lesions in Type II diabetic patients with overt proteinuria, however, are similar to those in patients with Type I diabetes [10]. Secondly that due to small sample size the previously reported positive finding [4] is spurious. So far there have been no other published reports examining this finding. In our recent large family based study conducted at the Joslin Diabetes Center we did not, however, find any linkage or association between polymorphisms in the promoter region (including $5^{\prime}$-ALR2) and diabetic nephropathy (unpublished data). This family study, known as the transmission disequilibrium test (TDT), can be considered as the most reliable approach to testing a role of genetic factors in the susceptibility to diabetic nephropathy. Taken together the negative findings from our family based study in Type I diabetes and the negative results in the present study can be considered strong evidence against the 5 '-ALR2 polymorphism as a "sensitive" marker for detecting susceptibility to diabetic nephropathy in Caucasian patients with Type II diabetes.

Finally, although our results suggest that the $5^{\prime}$ ALR2 polymorphism is unlikely to influence susceptibility to diabetic nephropathy in Type II diabetes, aldose reductase itself could still be important to the disease process as the first enzyme of the polyol pathway. Its expression could be influenced by other sequence differences in the $\mathrm{AR}$ gene that are not in linkage disequilibrium with the 5 '-ALR2 polymorphism or by other cellular components determining susceptibility to diabetic nephropathy.

Acknowledgements. D. K. Moczulski is a recipient of a fellowship from the Juvenile Diabetes Foundation number 397036. We thank Dr. A.S Krolewski (Harvard Medical School) for his valuable discussion and critical reading of this manuscript. 


\section{References}

1. Greene DA, Lattimer SA, Sima AAF (1987) Sorbitol, phosphoinositides and sodium-potasium-ATPase in the pathogenesis of diabetic complications. N Engl J Med 316: 599-606

2. Graham A, Brown L, Hedge PJ, Gammark AJ, Markham AF (1991) Structure of the human aldose reductase gene. J Biol Chem 266: 6872-6877

3. Ko BCB, Lam KSL, Wat NMS, Chung SM (1995) An (AC)n dinucleotide repeat polymorphic marker at the $5^{\prime}$ end of the aldose reductase gene is associated with early-onset diabetic retinopathy in NIDDM. Diabetes 44: 727-732

4. Heesom AE, Hibberd ML, Milward A, Demaine AG (1997) Polymorphism in the 5 '-end of the aldose reductase gene is strongly associated with the development of diabetic nephropathy in type I diabetes. Diabetes 46: 287-291

5. Imperatore G, Hanson RL, Pettitt DJ, Kobes S, Bennett PH, Knowler WC, Pima Indians Genes Group (1998) Sibpair linkage analysis for susceptibility genes for microvas- cular complications among Pima Indians with type 2 diabetes. Diabetes 47: 821-830

6. Warram JH, Gearin G, Laffel L, Krolewski AS (1996) Effect of duration of type I diabetes on the prevalence of stages of diabetic nephropathy defined by urinary albumin/creatinine ratio. J Am Soc Nephrol 7: 930-937

7. Patel A, Ratanachaiyavong S, Millward BA, Demaine AG (1993) Polymorphism of aldose reductase locus (ALR2) and susceptibility to diabetic microvascular complications. Adv Exp Med Biol 328: 325-332

8. Nelson RG, Bennett P, Beck GJ et al. Diabetic Renal Disease Study Group (1996) Development and progression of renal disease in Pima Indians with non-insulin-dependent diabetes mellitus. N Engl J Med 335: 1636-1642

9. Fioretto P, Mauer M, Brocco E et al. (1996) Patterns of renal injury in NIDDM patients with microalbuminuria. Diabetologia 39: 1569-1576

10. Osterby R, Gall MA, Schmitz A, Nielsen FS, Nyberg G, Parving HH (1993) Glomerular structure and function in proteinuric Type 2 (non-insulin-dependent) diabetic patients. Diabetologia 36: 1064-1070 